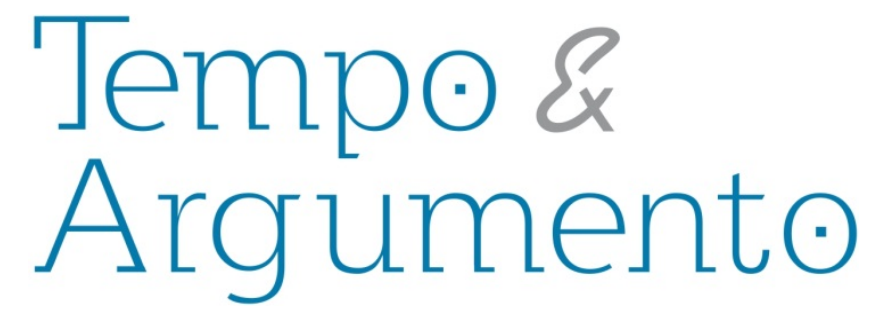

\title{
Os expurgos de 1964 e o discurso anticorrupção na caricatura da grande imprensa
}

\section{Resumo}

Este artigo aborda os discursos visuais e verbais da grande imprensa no contexto do Golpe de 1964, com ênfase no "segundo alvo" dos expurgos empreendidos pelo novo regime, qual seja, a corrupção. O estudo analisa o papel dos periódicos - em especial das caricaturas - na construção de representações que sustentaram a ditadura, notadamente no que se refere ao combate à corrupção. Para abordar adequadamente o objeto, busca-se perceber os interesses políticos e as manipulações discursivas dos atores envolvidos, que muitas vezes foram movidos por razões bem distantes da luta contra a corrupção.

Palavras-chave: Caricaturas; Política; Ditadura; Brasil - História - 1964-1985.

\author{
Rodrigo Patto Sá Motta \\ Doutor em História Econômica pela \\ Universidade de São Paulo. Professor da \\ Universidade Federal de Minas Gerais. \\ Brasil \\ rodrigopsamotta@gmail.com
}

\section{Para citar este artigo:}

MOTTA, Rodrigo Patto Sá. Os expurgos de 1964 e o discurso anticorrupção na caricatura da grande imprensa. Revista Tempo e Argumento, Florianópolis, v. 8, n. 18, p. 09 - 39. maio/ago. 2016. 


\title{
Purges of 1964 and anticorruption discourse in the caricature by mainstream press
}

\begin{abstract}
This article addresses the visual and verbal discourses of mainstream press in the context of the 1964 Brazilian Coup, with an emphasis on the 'secondary target' of the purges undertaken by the new regime, namely, corruption. The study analyzes the role played by periodicals - especially caricatures - in building representations that provided the dictatorship with support, mainly regarding the fight against corruption. In order to adequately approach the object, we try to grasp the political aims and discursive manipulations of the players involved, who were often driven by reasons very far from fighting against corruption.
\end{abstract}

Keywords: Caricature; Politics; Dictatorship; Brazil - History - $1964-1985$.

\section{Introdução}

Este artigo resulta de pesquisa acadêmica em andamento cujo foco são as representações construídas pela grande imprensa acerca do regime militar $^{1}$. Seu objetivo é compreender as relações estabelecidas entre as empresas jornalísticas do eixo Rio-São Paulo e a ditadura. Todos os veículos da grande mídia - com exceção de Última Hora apoiaram decididamente a intervenção militar, contribuindo para configurar o notável apoio civil conquistado pelos golpistas de 1964. Entretanto, o apoio da imprensa não significou a ausência de críticas e de discordâncias com os novos donos do poder. No decorrer da longeva ditadura brasileira, ocorreram episódios de tensão envolvendo alguns veículos da grande mídia e o Estado. Nesses momentos, em geral, as crises

\footnotetext{
${ }^{1}$ A pesquisa é financiada pelo Conselho Nacional de Desenvolvimento Científico e Tecnológico (CNPq), por meio de bolsa de produtividade, e também contou com recursos da Fundação de Amparo à Pesquisa do Estado de Minas Gerais (Fapemig).
} 
A grande mídia apoiou os expurgos (em alguns casos chegou a exigi-los) e as ações autoritárias que considerava justas para combater a esquerda e garantir a manutenção da ordem social e econômica. Entretanto, ao mesmo tempo, não desejava que o autoritarismo implicasse limites à sua liberdade, por isso discordava da censura. Em sua maioria, os jornais perfilavam com a ala "liberal" dos apoiadores de 1964, setores que temperavam seu amor pela liberdade com notável transigência a intervenções autoritárias para defesa do status quo. Por isso, as relações da imprensa com o Estado ao longo da ditadura foram marcadas por complexidades e ambiguidades, variando entre o apoio entusiástico e a crítica, situação semelhante, aliás, à de outros setores da sociedade.

Neste artigo, o foco recai sobre as representações da imprensa dos expurgos, uma das ações permanentes e definidoras do regime autoritário. Serão abordados, principalmente, os primeiros meses do novo regime, quando a "operação limpeza" deu o tom dos procedimentos inaugurais da ditadura. É fundamental estudar cuidadosamente esse momento inicial, porque ali se definiram as linhas básicas do novo regime político, inclusive a construção de seu par de inimigos (e alvos) principais: a subversão (mais precisamente, o comunismo) e a corrupção. No texto será atribuída ênfase ao segundo tema, com o objetivo de mostrar o papel da imprensa e das caricaturas na construção das representações da corrupção e seu lugar nos discursos de fundação e de legitimação da ditadura. Vamos nos deter, em especial, em dois casos marcantes no combate à corrupção, nos quais foram alvo figuras estelares do universo político brasileiro: Juscelino Kubitschek (JK) e Ademar de Barros. As representações caricaturais dos processos de cassação de ambos mostram os limites entre a convicção moralizadora e os interesses políticos dos agentes envolvidos.

Embora a pesquisa que fundamenta este artigo englobe simultaneamente os discursos visuais e os discursos verbais da imprensa, o texto aborda principalmente as caricaturas $^{2}$. Move-nos o interesse de compreender o papel assumido pelas caricaturas e

\footnotetext{
${ }^{2}$ Aqui, os termos caricatura e charge são usados indistintamente, com base no conceito de que caricatura é a expressão original para a arte do humor gráfico (de que charge é uma tradução para o francês) e serve
} 
conferir a devida atenção às especificidades da linguagem caricatural e seu potencial comunicativo com o grande público. Os grafismos cômicos constituem comentários diários dos acontecimentos e dos atos dos líderes políticos, o que os torna uma espécie de crônica visual dos eventos políticos. Assim, auxiliam os jornais em seu papel de produzir notícias e influenciar a opinião política. Vale enfatizar o último aspecto: as caricaturas não apenas comentaram passivamente os acontecimentos, mas também participaram dos embates e ajudaram a pautar o debate político, exercendo pressão em favor das opiniões dos proprietários do jornal.

Importa destacar as peculiaridades expressivas e comunicativas do humor gráfico. Por mobilizar recursos de comicidade e por sua capacidade de concisão, as caricaturas são instrumento significativo de popularização do debate político, notadamente em contexto de elevado analfabetismo. Entretanto, analisar os efeitos políticos dos grafismos cômicos é trabalho mais difícil, pois frequentemente são dúbios. Certos ataques caricaturais podem ser corrosivos para seus alvos, ao divulgar imagens negativas, enfraquecendo determinados líderes. Entretanto, também podem contribuir para humanizar a figura do líder, tornando-o mais próximo e mais compreensível para o cidadão comum ${ }^{3}$. Ainda sobre os efeitos políticos da caricatura, outra questão complexa é saber se a crítica cômica acirra os ânimos e estimula a mobilização, ou, ao contrário, promove o relaxamento das tensões e estimula a tolerância.

De qualquer modo, não se deve exagerar no tema das singularidades da linguagem caricatural. De um lado, porque normalmente as imagens expressam, mais que opiniões pessoais, o ponto de vista do jornal. Certos desenhistas conseguem ter alguma autonomia, porém, situações de desencontro entre as caricaturas e a linha editorial do periódico são raras. Muitas vezes, as caricaturas se restringem à função de charge

de designação genérica para várias formas de desenho cômico. No entanto, existe um debate conceitual sobre as especificidades e diferenças entre os dois termos, com alguns autores defendendo usos distintos para caricatura e charge. Para uma apreciação recente desse debate ver ROMERO, Marcelo. O governo Fernando Henrique Cardoso na charge de Angeli: os tons e contornos da crítica política no traço do artista. Tese de Doutorado em História, UFJF, Juiz de Fora, 2015.

${ }^{3}$ A esse respeito ver DELPORTE, Christian. Les ambivalences du pouvoir e des politiques. In DELGADO, Marie-Melódie (org.). La caricature ... et si c'était sérieux? Décryptage de la violence satirique. Paris, Nouveau Monde Éditions, 2015, p.48-57. 
Em que pesem tais observações, houve momentos em que as caricaturas da grande imprensa trouxeram contribuição original aos discursos - e às polêmicas políticas. Em alguns casos, os desenhistas usaram o potencial criativo de sua arte para criar imagens novas ou para trabalhar conceitos antigos em novo formato, produzindo efeitos cômicos e políticos marcantes. Voltaremos ao tema da contribuição original adiante, ao analisar a representação caricatural da corrupção.

Pelo que foi dito, evidenciam-se os desafios diante de qualquer tentativa de avaliar os efeitos políticos das caricaturas. Tanto mais porque é difícil - embora não impossível estudar a recepção das imagens ou seu impacto sobre o público. De todo modo, tal constatação não reduz a importância do objeto em foco. Segue sendo importante pesquisar as maneiras como a imprensa representou as ações da ditadura e produziu imagens referentes ao novo poder. Nessas representações visuais, encontramos um decidido apoio à ditadura, mas também críticas e pressões para tentar conduzir as ações do Estado na direção desejada pelos controladores dos periódicos.

Últimas observações introdutórias, e sumárias, de caráter metodológico. Devido à amplitude do país, seria muito difícil trabalhar com jornais em escala nacional. A opção de usar diários do eixo Rio-São Paulo deveu-se à sua maior circulação e capacidade de influenciar a imprensa dos outros estados ${ }^{4}$. A pesquisa resultou na coleta de grande número de imagens, porém, para este artigo, foram selecionadas as que pareceram mais relevantes pelo critério de expressividade política e cômica. Mesmo tendo descartado muitas imagens durante o processo de seleção, ao final se obteve elevado número de charges e caricaturas, cuja inclusão no artigo implicou a necessidade de uma síntese pela limitação de espaço para a análise. Foi uma opção consciente, baseada na convicção de ser preferível mostrar um número significativo de imagens, mesmo que isso obrigue a uma análise sumária, em vez de usar poucas imagens e destrinchá-las nos mínimos detalhes. Uma amostragem maior traduz melhor a riqueza das representações

\footnotetext{
${ }^{4}$ A pesquisa em que está baseado este artigo se concentrou nos seguintes diários: O Estado de São Paulo, O Globo, Jornal do Brasil, Folha de São Paulo, Correio da Manhã e Última Hora.
} 
Pela mesma razão, tampouco será possível analisar com o devido cuidado as peculiaridades do trabalho de cada artista, com igual justificativa. O objetivo, aqui, é interpretar a mensagem política central contida nas imagens ${ }^{5}$, na tentativa de entender as posições defendidas pelos jornais. As diferenças de opinião política entre os periódicos serão indicadas ao longo do texto, notadamente no que respeita à questão dos expurgos, como logo se verá.

\section{Os expurgos na visão da grande imprensa}

Nos primeiros anos da ditadura e até pelo menos a crise do Al5, vários diários da grande imprensa reivindicaram a "revolução" como uma obra sua também, por isso mesmo usaram a palavra sem aspas. Como "revolucionários" de primeira hora, eles reclamaram o direito de influenciar os rumos do novo regime, atuando como força de pressão e aliando-se a certas facções políticas. O caso mais marcante foi O Estado de São Paulo, que se engajou na ditadura de corpo e alma a partir da militância de seu proprietário, Júlio de Mesquita Filho. Depois do Al5, o Estadão iria entrar em rota de colisão com a ditadura (assim como seus chargistas), por isso foi submetido ao mecanismo da censura prévia entre 1972 e 1975. Entretanto, nos meses iniciais pós-golpe, esse diário apoiou enfaticamente a política repressiva do novo regime. Outro diário da grande imprensa com entusiasmo equivalente pela ditadura foi $O$ Globo, que publicou inúmeros textos em favor do governo golpista e dos expurgos por ele promovidos. Contudo, naquele período o jornal não publicava caricaturas políticas, ao contrário do Estadão, que contava com o talento de Hilde e de Biganti ${ }^{6}$.

Entre abril de 1964 e o final de 1965, O Estado de São Paulo foi uma espécie de porta-voz da linha-dura, exigindo rigor na repressão aos "comunistas e subversivos". Na visão dos controladores do jornal, o novo governo deveria ser uma ditadura com prazo

\footnotetext{
${ }^{5}$ A metodologia utilizada na análise e interpretação das caricaturas foi desenvolvida em publicações anteriores, notadamente em MOTTA, Rodrigo P.S. Jango e o golpe de 1964 na caricatura. Rio de Janeiro, Zahar, 2006 e MOTTA, Rodrigo P.S. A ditadura nas representações verbais e visuais da grande imprensa: 1964-1969. Topoi, v. 14, n. 26, jan./jul. 2013, p. 62-85.

${ }^{6}$ Hilde Weber (1913-1994) e Edmondo Biganti (1918-2000).
} 
esmorecesse na luta contra seus inimigos. As charges de Hilde e Biganti acompanharam com fidelidade a linha editorial de $O$ Estado de São Paulo e ofereceram uma expressão visual da opinião do diário paulista. Por vezes, eles se limitaram a ilustrar os textos, mas, em outros casos, foram mais criativos, elaborando artifícios visuais que ofereceram novas possibilidades para representar as posições do jornal, em especial no tema da corrupção, como será mostrado.

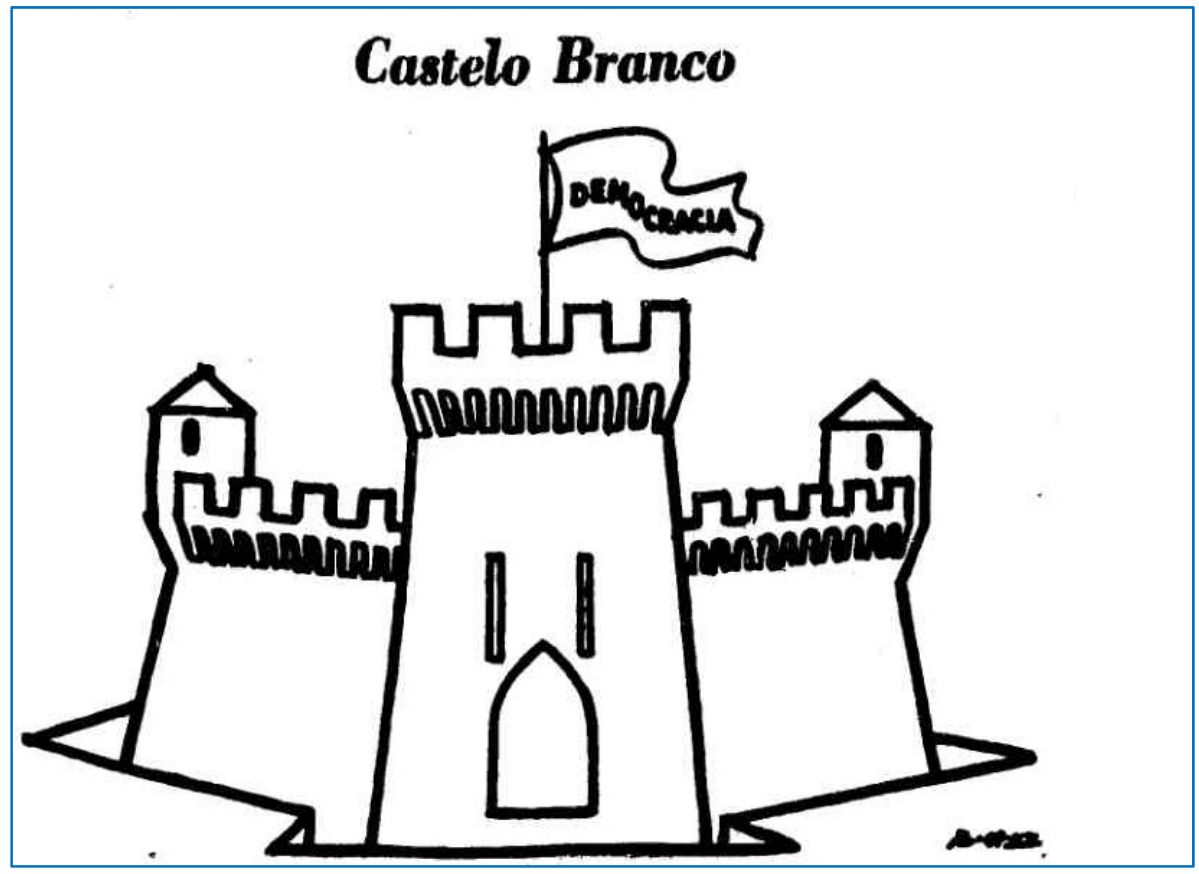

Figura 1. O Estado de São Paulo, 08/04/1964. Biganti

Nos primeiros dias de vigência da ditadura, quando os golpistas ainda definiam o nome para ocupar a presidência da República, Biganti adotou a metáfora do Castelo para representar o regime de 1964. A metáfora revelava a preferência pelo general Castelo Branco entre os postulantes ao cargo de presidente e indicava as expectativas em relação ao novo governo, bem como o papel dirigente dos militares. Como se vê na charge da Figura 1, a fortaleza representava a solidez do novo poder e sua capacidade de preservar a ordem "democrática” contra qualquer oponente. 


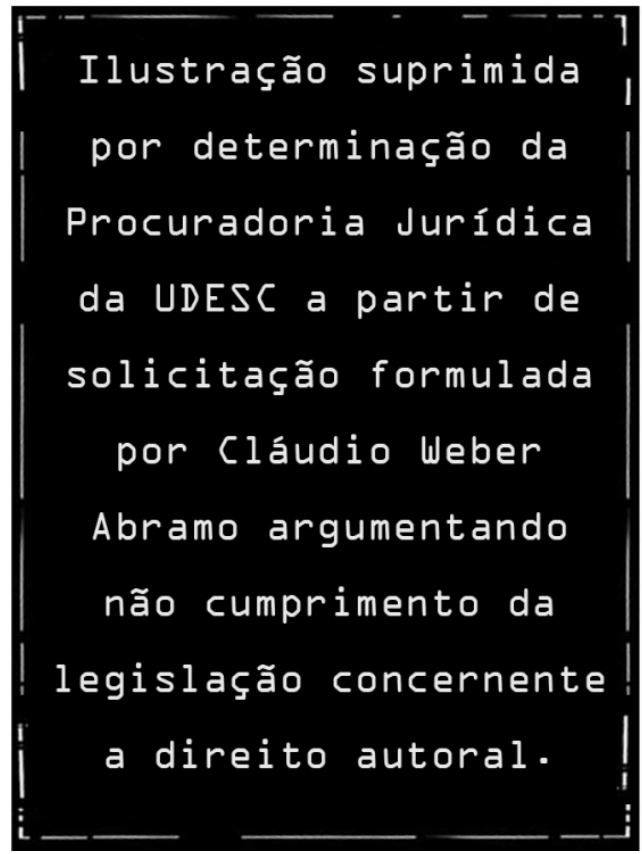

Figura 2. O Estado de São Paulo, 15/04/64, Hilde

O suposto respeito à democracia não era visto como contraditório em relação ao expurgo dos inimigos derrotados e à suspensão de seus direitos, que os desenhos publicados no periódico defenderam com denodo. Os chargistas do Estadão apoiaram os expurgos e as cassações com entusiasmo ímpar, como se pode ver na Figura 2, que mostra o Congresso Nacional sendo metaforicamente dedetizado. A charge sugere a presença de pragas e doenças a serem exterminadas no Congresso e oferece uma metáfora crua, embora apresentada comicamente, sobre a natureza dos expurgos, já que, além de não ter sido oferecido o direito à defesa, muitos parlamentares e líderes políticos também foram encarcerados. Em charge publicada alguns dias depois e reproduzida na Figura 3, Hilde voltou ao expurgo dos parlamentares de maneira nada sutil, mostrando com aprovação o porrete da "revolução" quebrando o estatuto da imunidade parlamentar. Uma imagem eloquente do significado repressivo do 31 de março. O alvo da punição era Moisés Lupion (note-se o M.L. na charge), político paranaense acusado de corrupção quando ocupou o governo de seu Estado, que teve seu mandato de deputado federal cassado nos primeiros dias do golpe. 


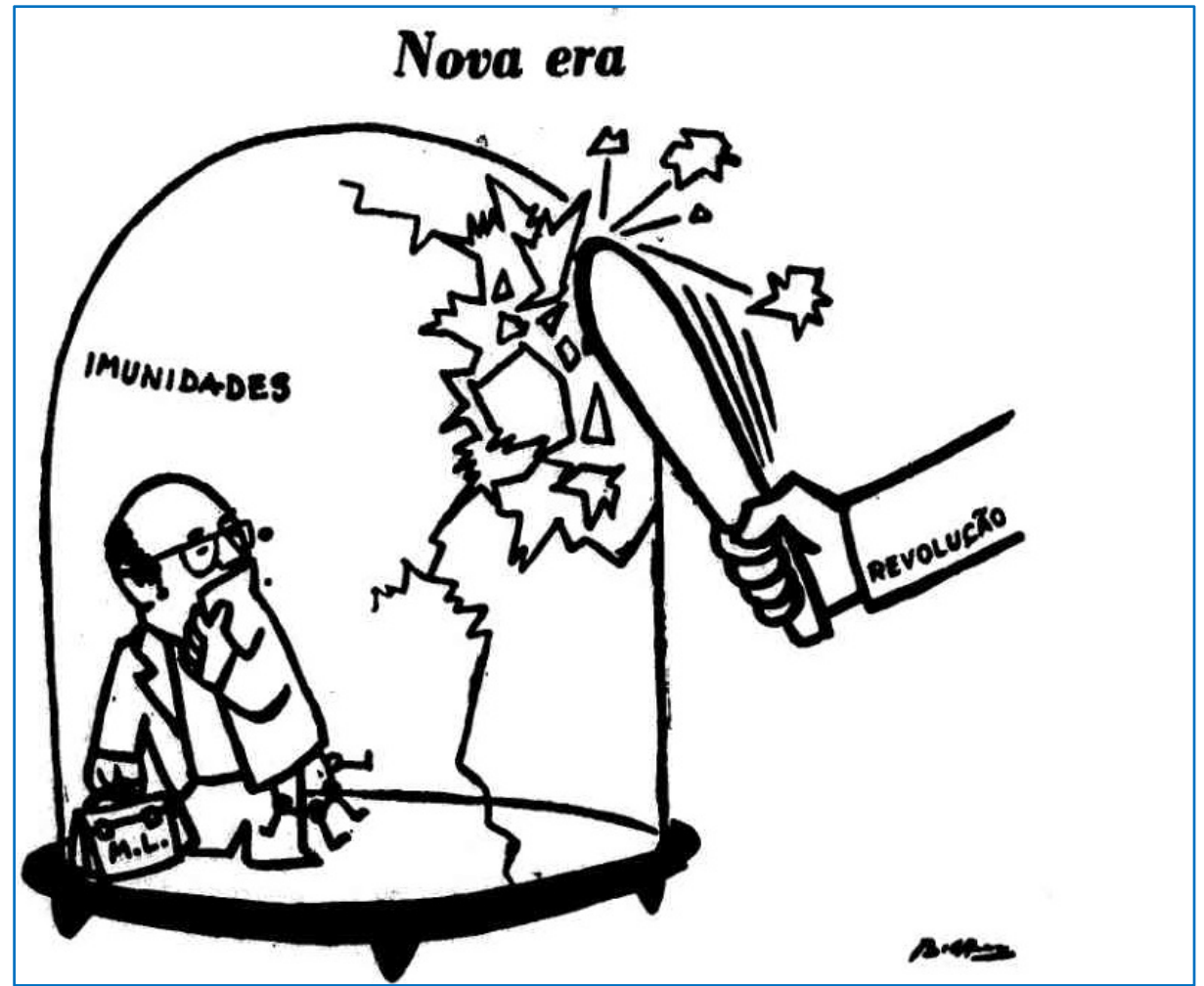

Figura 3. O Estado de São Paulo, 17/04/64, Biganti

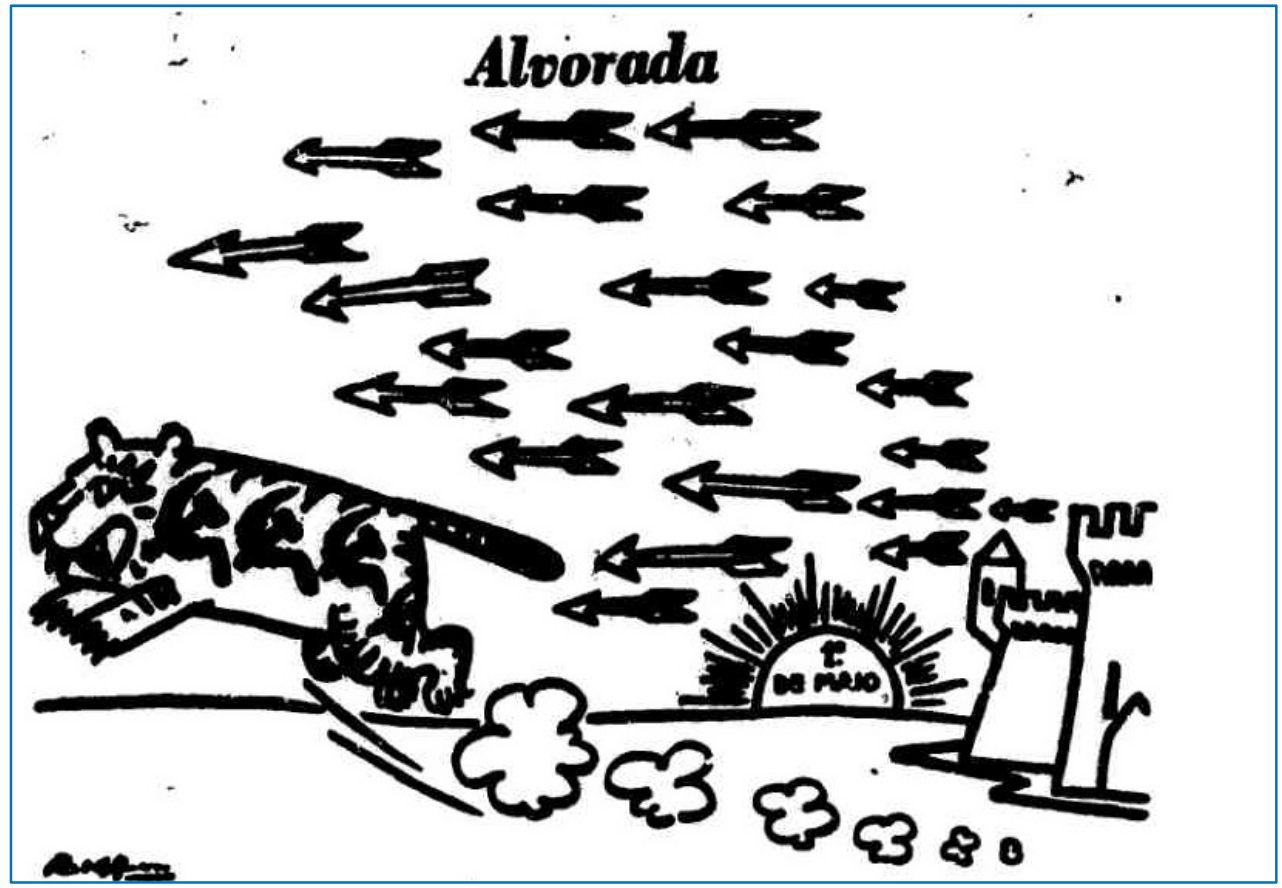

Figura 4. O Estado de São Paulo, 01/05/64. Biganti

Na Figura 4 vemos novamente a "revolução" como um castelo/fortaleza, dessa vez em versão mais agressiva, pois o inimigo principal é alvejado com flechas. A imagem 
alude à data comemorativa do trabalho, $01^{\circ}$ de maio, e dialoga com o editorial publicado na mesma edição do periódico. Segundo esse editorial, o presidente Castelo Branco iria participar das comemorações junto com o operariado e deveria transmitir uma mensagem fundamental. De acordo com o texto, a derrota da extrema-esquerda e da demagogia anunciava uma nova era nas relações do Estado com os trabalhadores. Esperava-se que em seu discurso Castelo Branco convidasse o operariado a aceitar "o regime de austeridade e disciplina que a conjuntura nacional exige". Na charge, a alvorada do novo dia do trabalho mostra o Castelo atirando flechas e colocando em fuga o tigre comunista, uma sugestão da forma como se alcançaria a "disciplina" do operariado.

Outra alusão significativa à operação limpeza pode ser vista na Figura 5, uma representação sobre os expurgos na Assembleia Legislativa de São Paulo, que estavam em discussão nos bastidores políticos. Como ainda não havia nada de concreto, fica mais evidente a posição favorável ao expurgo no legislativo paulista, mais do que isso, a charge significava um convite à ação. O desenho alude à cafeicultura como símbolo de São Paulo, sugerindo que o parlamento estadual deveria proceder como os agricultores do café, expurgando os frutos ruins.

Ilustração suprimida

\section{por determinação da}

Procuradoria Jurídica

da UDESC a partir de

solicitação formulada

por Cláudio Weber

Abramo argumentando

não cumprimento da

legislação concernente

a direito autoral.

Figura 5. O Estado de São Paulo, 08/05/64, Hilde 
Enfim, há inúmeras charges no Estadão comentando favoravelmente os expurgos, com uma tendência a privilegiar o ataque à esquerda nas primeiras semanas de abril, sendo que logo a seguir o alvo principal passou a ser a corrupção, especialmente com foco em JK e Ademar, como será mostrado na próxima seção. Tamanho engajamento torna a charge da Figura 6 pouco surpreendente, configurando clara manifestação de lamento pelo fim do período de cassação de mandatos políticos ${ }^{7}$. Hilde ironizou o fim das cassações do Al como um gato que saía do cenário, deixando felizes os ratinhos da subversão, sonegação e corrupção. Mais sobre a figura do rato em breve.

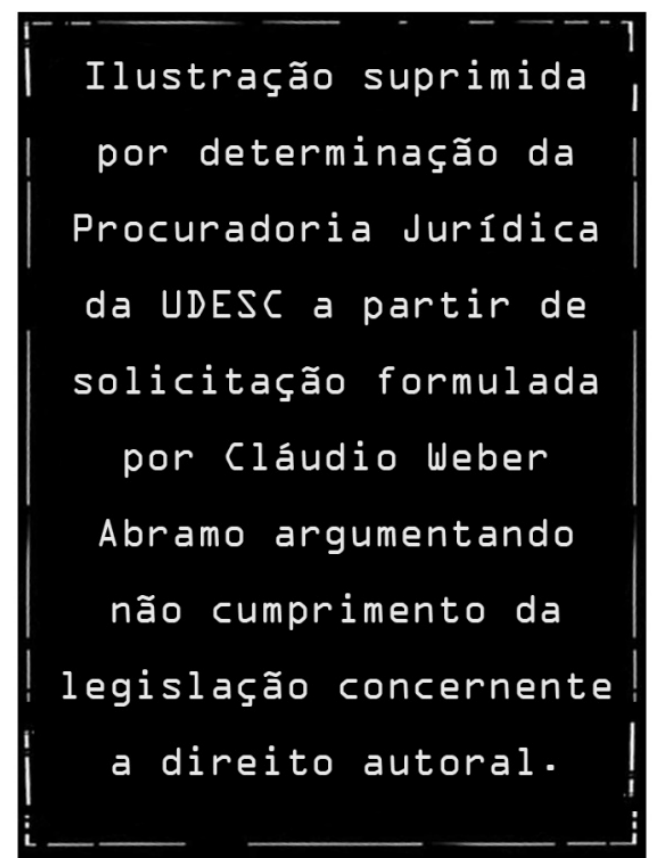

Figura 6. O Estado de São Paulo, 23/06/64. Hilde

Vejamos agora como outros jornais da grande imprensa trataram o tema dos expurgos. Entre o grupo de diários pesquisados, o Jornal do Brasil e a Folha de São Paulo igualmente apoiaram a "limpeza", em especial contra a esquerda. Entretanto, não demonstraram o mesmo empenho repressivo e chegaram a criticar o que consideraram ações exageradas e injustas. Decerto, deve-se a tal linha editorial mais cautelosa a ausência de comentários caricaturais favoráveis aos expurgos. Quando as charges do Jornal do Brasil e da Folha abordaram os expurgos o fizeram em tom de ironia crítica.

\footnotetext{
7 O Ato Institucional havia conferido dois meses de prazo ao Poder Executivo para a cassação de mandatos parlamentares e suspenção de direitos políticos (para o expurgo de servidores públicos o prazo foi maior, seis meses).
} 
Discursos visuais e verbais criticando de modo contundente os expurgos foram encontrados nos diários Última Hora e Correio da Manhã. No primeiro caso, era uma atitude esperada, em vista das ligações do periódico com o governo deposto. Entretanto, no caso do Correio, tratou-se de mudança de posição, já que esse tradicional diário havia apoiado a deposição de João Goulart, para logo se desencantar quando o novo regime se afirmou como ditadura. Na série de imagens ironizando os expurgos que encontramos nas charges de Última Hora e Correio merecem destaque, por sua expressividade e estilo, alguns desenhos de Augusto Bandeira ${ }^{8}$ publicados no último. Na Figura 7, vê-se uma cena natalina, com os generais Castelo Branco e Costa e Silva (então no cargo de Ministro da Guerra) usando as cabeças “decepadas” de vários políticos proeminentes como bolas decorativas para sua árvore. Já estão pendurados Goulart, Miguel Arraes e JK, cassados nos meses anteriores, e Castelo Branco procura um lugar na árvore para a cabeça de Mauro Borges, governador de Goiás que acabara de ser cassado. Mas há outras opções a serem utilizadas para concluir a decoração, e Costa e Silva analisa um grupo de cabeças que podem ser as próximas vítimas do expurgo, como Magalhães Pinto, Ademar de Barros e Carlos Lacerda (posteriormente, os dois últimos foram cassados de fato).

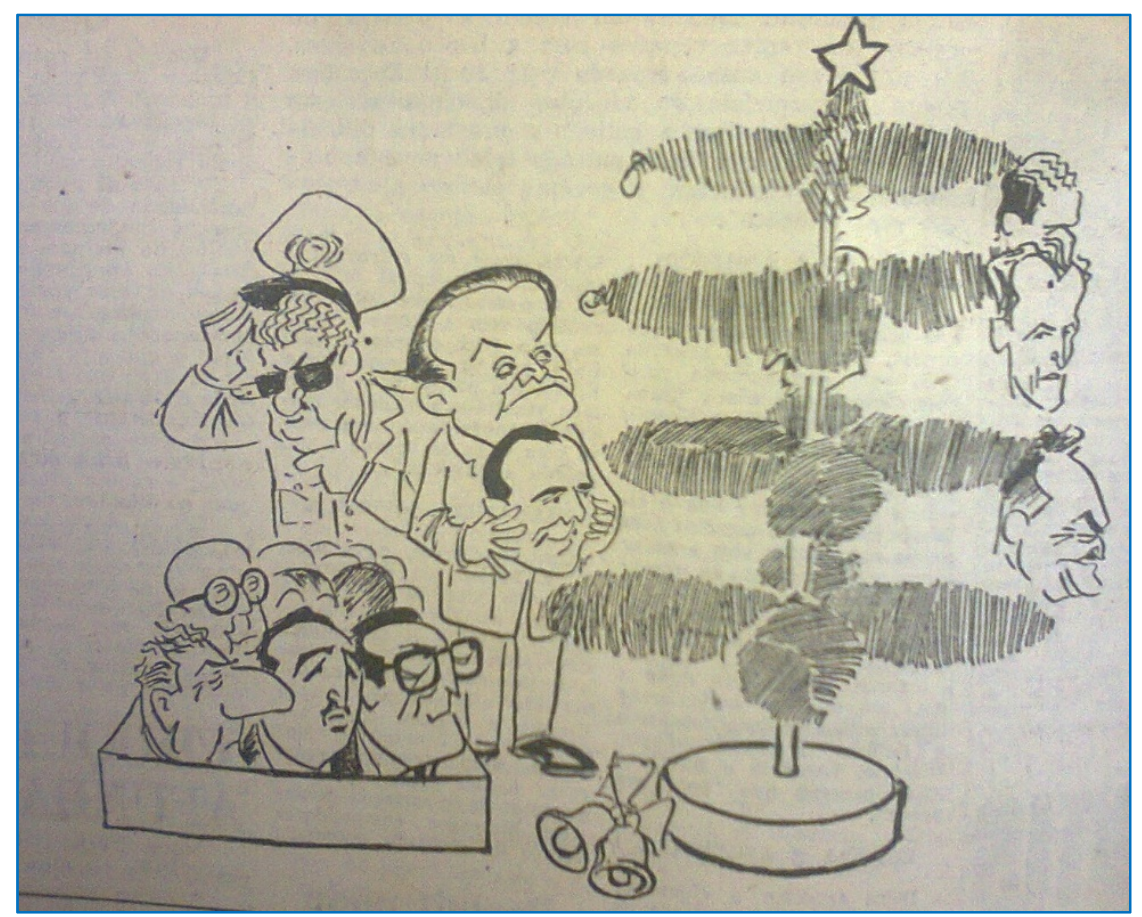

Figura 7. Correio da Manhã, 27/11/64. Augusto Bandeira

\footnotetext{
${ }^{8}$ Carlos Augusto Moniz Bandeira (1937-2000).
} 
No caso da Figura 8, vemos uma hilária cena desenhada por Bandeira aludindo às situações ridículas e aos exageros que ocorreram em meio à caça às bruxas. No quadro, há um grupo de agentes "revolucionários" em que predominam policiais e militares, um deles portando um inquérito policial militar (IPM). Em destaque, aparecem Castelo Branco e Carlos Lacerda, na condição de chefes do grupo cercando a estátua de São Sebastião, como se o santo fosse também um subversivo comunista, ao que ele responde, indignado contra tamanho absurdo, reiterando sua inocência.

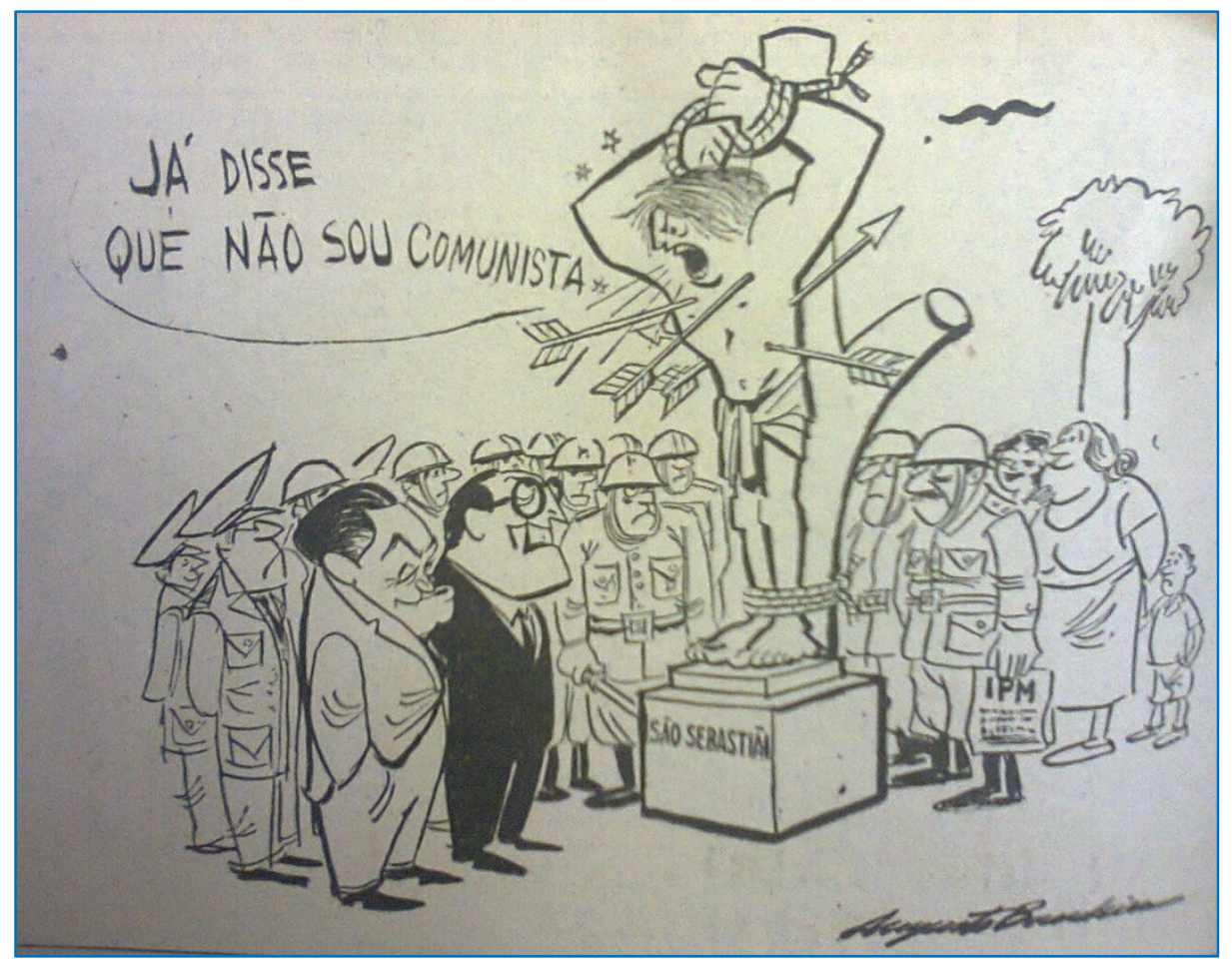

Figura 8. Correio da Manhã, 21/01/64. Augusto Bandeira

\section{Mirando o segundo objetivo da "Revolução": a luta contra a corrupção}

Os discursos dos vitoriosos de 1964 apresentaram o objetivo de livrar o país de dois males, que seriam seus principais inimigos: a subversão comunista e a corrupção. 0 par de inimigos foi, ao mesmo tempo, uma motivação para o movimento golpista e uma justificativa para a violência e o desrespeito contra os direitos e as garantias dos cidadãos cometidos pela ditadura. Na campanha contra o governo Goulart, a temática 

político, como o Ato Institucional de 9 de abril de 1964, que justificou suas ações com a afirmação de que o presidente deposto pretendia bolchevizar o país e apresentou como seu objetivo central "drenar o bolsão bolchevista”.

A temática da luta contra a corrupção assumiu centralidade no discurso dos líderes do golpe somente após o sucesso do movimento militar, quando ficou evidente que a ameaça comunista havia sido superestimada. De fato, foi no período imediatamente posterior ao 31 de março de 1964 que se consolidou o discurso sobre o inimigo duplo, ressaltando que para alguns grupos de direita tratava-se do mesmo problema, pois enxergavam comunismo e corrupção imbricados um no outro. É fundamental referir que a imprensa favorável ao golpe teve papel-chave na construção da imagem do duplo inimigo, especialmente a figura da corrupção, com contribuição destacada de O Globo e do Estadão. Após a ênfase inicial no tom anticomunista, ambos passaram a assestar baterias também contra a corrupção, orientação que foi fixada em dois editoriais marcantes.

No caso do jornal carioca, o marco foi o editorial "Início de uma era de honestidade e decência", publicado em 18/04/1964, no qual o editorialista comentou favoravelmente a posse de Castelo Branco. Após comemorar a chegada do novo governo e afiançar expectativas positivas, o editorial alerta que não é suficiente punir aqueles "que se mancomunaram para substituir o nosso regime pelo marxismo-leninismo". Também se deveria sanear a corrupção e os corruptos, que, aliás, segundo o texto, teriam auxiliado a campanha dos comunistas. A mesma inflexibilidade que vinha mostrando contra os agitadores e comunistas, afirmava o diário, o governo também deveria ter diante dos "ladrões dos dinheiros públicos". O combate à corrupção seria uma das principais expectativas da população, dizia o texto, como a fazer um convite e mostrar ao governo um caminho para incrementar sua popularidade.

\footnotetext{
${ }^{9}$ Cf. MOTTA (2006).
} 
Quanto ao Estadão, é certo que a corrupção já aparecia em textos anteriores como um problema a ser combatido pelo novo governo. Entretanto, a ênfase inicial era sobre o expurgo anticomunista, como no editorial de 07/04/1964, que associou a operação limpeza à punição das forças subversivas obedientes aos "planos do comunismo internacional". Por isso, o editorial de 21/04/1964 ("Os postulados da Revolução") representou inflexão marcante ao fixar a ideia de que havia dois inimigos principais a combater e não apenas um. Vale a pena citar dois excertos da parte inicial do texto:

Nos círculos políticos de Brasília começa-se, finalmente, a compreender que o movimento revolucionário de 31 de março não teve unicamente em vista o desmonte das posições comunistas nos vários setores do Estado. Se a obra da Revolução parasse aí, não tardaria que nos víssemos a braços com os mesmos, senão com mais espinhosos problemas, do que aqueles que nos forçaram a depor militarmente o governo do sr. Goulart.

$[\ldots]$

Não são apenas os caudatários de Kruchev e Chu En-lai que estão em discordância com os objetivos saneadores da Revolução brasileira. Estãono, do mesmo modo e no mesmo grau, todos aqueles que, por meio da corrupção, do nepotismo e do suborno, concorreram fortemente para o descalabro econômico, político e moral a que chegamos.

Em que pese a importância dos editoriais, as caricaturas e charges tiveram papel fundamental na construção do tema da corrupção e dos corruptos. Significativamente, na edição do Estadão de 14 de abril de 1964, portanto antes do editorial acima referido, Biganti publicou uma charge intitulada "Segundo objetivo" (Figura 9). Nesse desenho, o artista adotou uma metáfora visual para a corrupção que teria largo uso nos meses seguintes, a ratazana. Essa charge ajudou a construir as representações visuais sobre a corrupção agregando ao tema um bicho repelente no imaginário popular, que foi mobilizado para aludir à "sujeira" que se pretendia limpar ${ }^{10}$. Vale notar a representação da "Revolução" como uma senhora com ares de dona de casa, solução visual muito

\footnotetext{
${ }^{10}$ Eram ratazanas ou ratos de pelo escuro, que são mais frequentemente associados no imaginário popular à sujeira e imundície. Claro que não era a primeira referência política a rato como sinônimo de corrupção. Por exemplo, no contexto das eleições presidenciais de 1945, o candidato apoiado pelos comunistas, Yedo Fiúza, foi alcunhado de rato por Carlos Lacerda, como referência a acusações de corrupção em cargos públicos que ocupara anteriormente. Lacerda publicou uma coletânea dos textos jornalísticos que escreveu contra o "rato Fiúza".
} 
utilizada nas charges devido ao gênero feminino da palavra revolução, mas, também uma menção ao apoio de grupos de mulheres de direita ao golpe. Na imagem, a senhora usara o porrete para abater a "serpente" comunista e se preparava para pegar outro bicho repulsivo, o rato, que representa a corrupção, ou seja, o "segundo objetivo" dos expurgos.

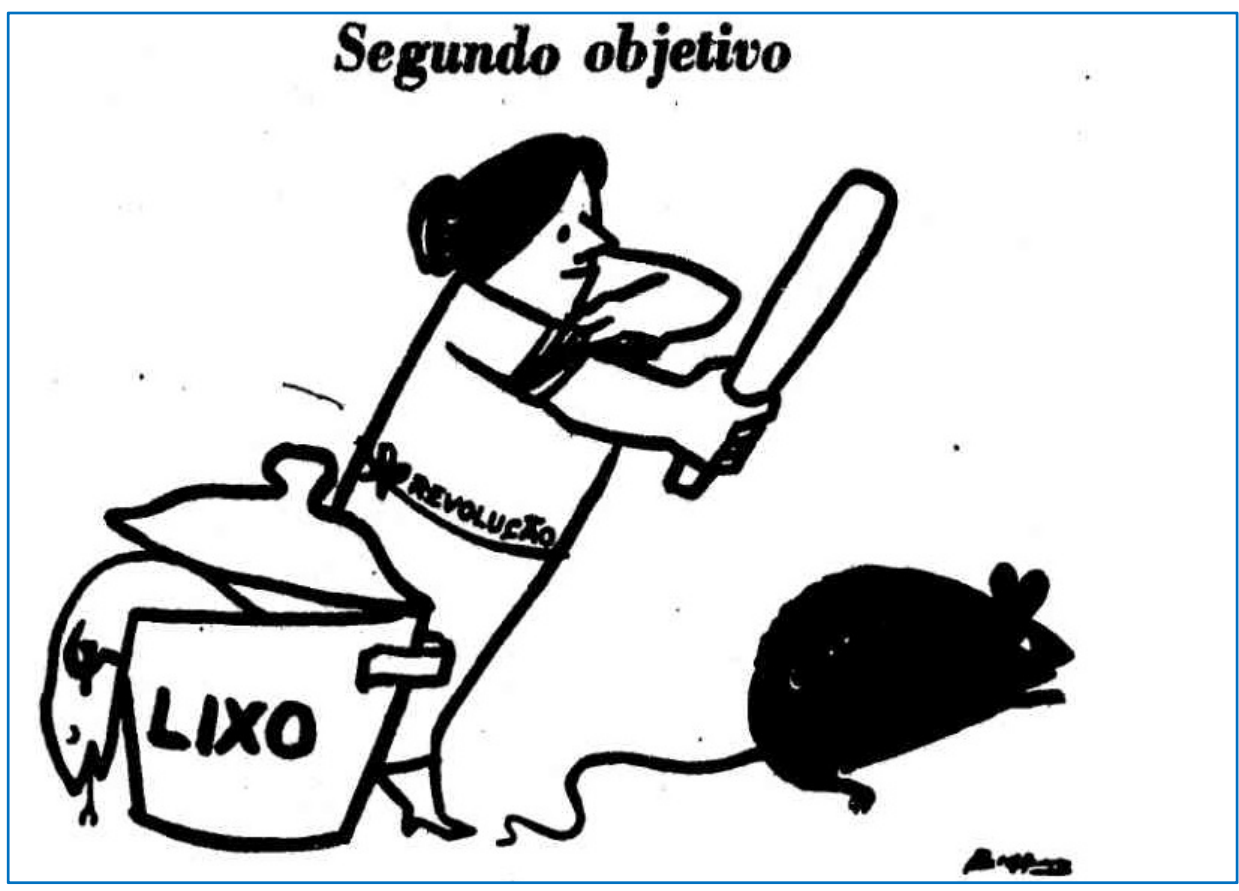

Figura 9. O Estado de São Paulo, 14/04/64, Biganti

No processo de construção dos discursos anticorrupção, as imagens apareceram simultaneamente aos discursos verbais, às vezes antes, de maneira que, ao invés do texto inspirar a charge, nesse caso pode ter sido o contrário, ou seja, os desenhos deram contribuição original para fixar a corrupção como segundo objetivo/alvo. De qualquer modo, o desenho cômico ofereceu novas alternativas aos ataques discursivos contra os inimigos da ditadura, alcançando efeitos singulares. Foram usadas outras metáforas para indicar a corrupção, como piratas e hidras ${ }^{11}$, por exemplo, mas a imagem das ratazanas trouxe melhores efeitos e inspirou inúmeras charges, às vezes aludindo também à subversão, como na charge de Hilde reproduzida na Figura 6.

\footnotetext{
${ }^{11}$ Conferir, respectivamente, as edições de 26/04/1964 e de 27/10/1964 de O Estado de São Paulo.
} 
Mais duas charges do Estadão que mobilizaram o tema das ratazanas merecem destaque e foram reproduzidas nas figuras 10 e 11 . No primeiro caso, trata-se de referência ao expurgo de servidores públicos estaduais de São Paulo, que foram aposentados ou demitidos com base no artigo $7^{\circ}$ do Ato Institucional. Os pinos de boliche derrubados pelo Al representam, principalmente, os professores e cientistas aposentados na USP e no Instituto Butantã, figurados por meio de convenções gráficas que evocam homens do saber - os óculos, as barbas, a calva. Contudo, entre eles também há alguns ratos, uma sugestão de que funcionários corruptos teriam sido atingidos pelo expurgo. Nota-se na imagem um sentido de aprovação à medida, especialmente devido ao título.

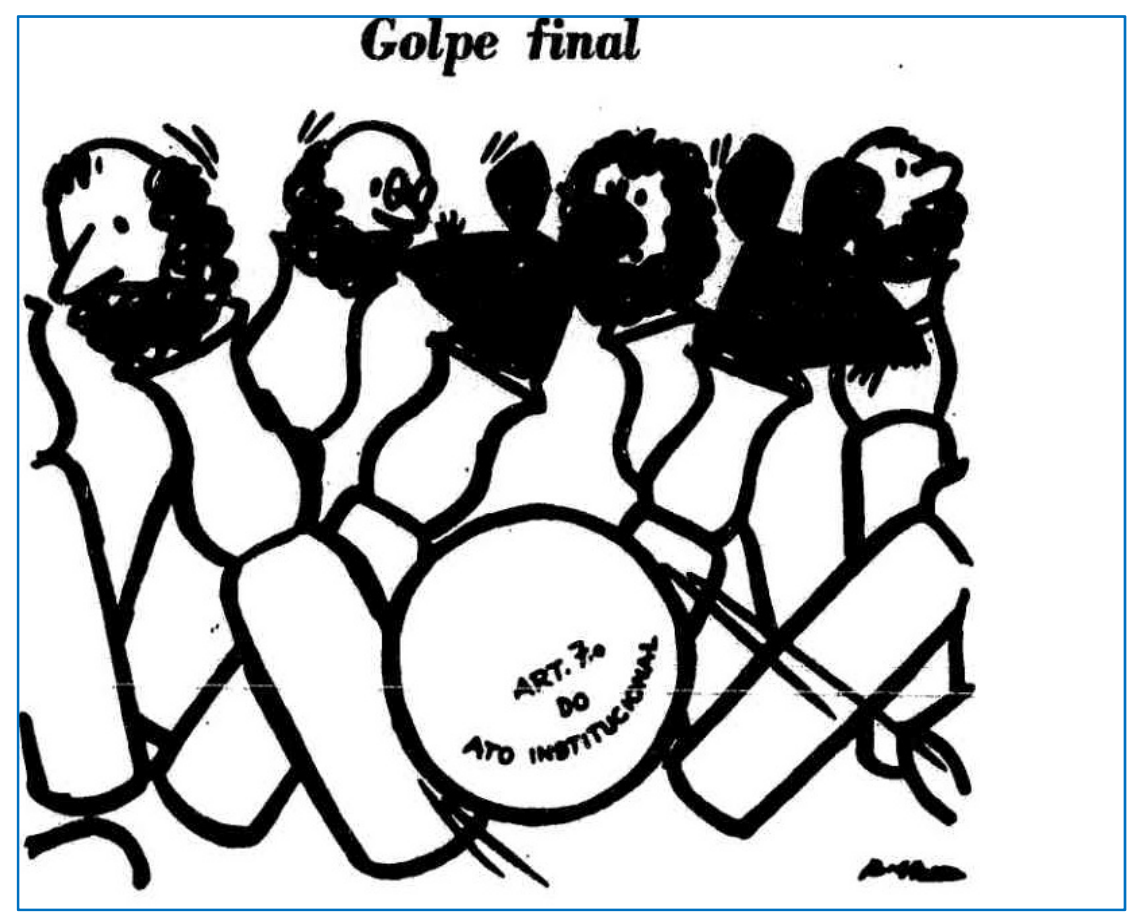

Figura 10. O Estado de São Paulo, 10/10/64, Biganti

Já no caso da Figura 11, trata-se de crítica do chargista ao governo, mas não por discordar dos expurgos, ao contrário, ele ataca sua suposta ineficiência e incompletude. A charge indica uma falha na "limpeza" do novo regime, usando a ratazana para mencionar que a corrupção não estava sendo atingida pela vassoura banguela do governo. Muitas outras charges de teor semelhantes foram publicadas nesse período, em geral, com menção implícita ou explícita a certos líderes políticos acusados de corrupção. 


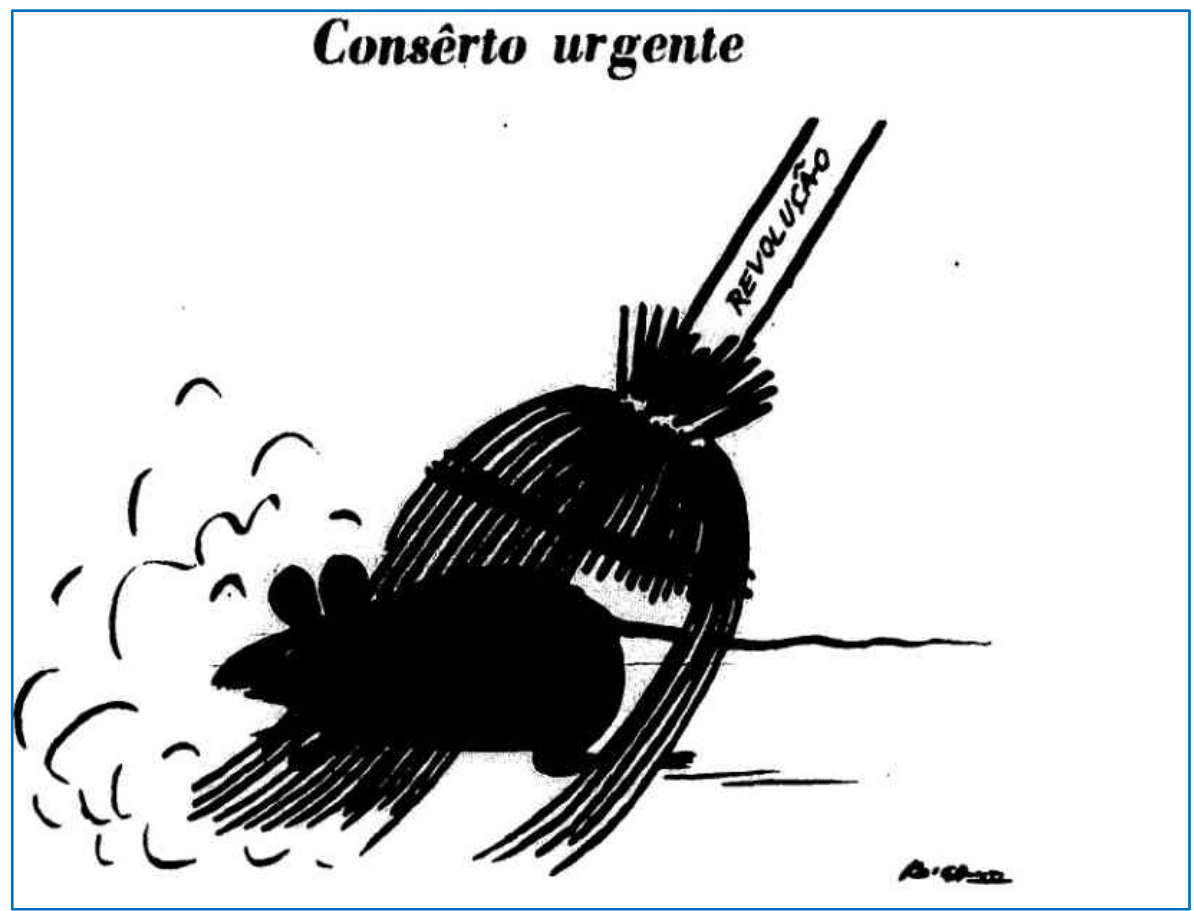

Figura 11. O Estado de São Paulo, 14/08/64. Biganti

\section{Juscelino Kubitschek e Ademar de Barros na mira}

A campanha da imprensa "revolucionária" a favor do expurgo da corrupção, com bastante frequência, indicava alvos precisos a serem atingidos pelos instrumentos de exceção da ditadura. Entre as lideranças políticas presentes no cenário, duas figuras tiveram destaque nas representações da imprensa atacando a corrupção: JK e Ademar de Barros.

Comecemos pelo caso do ex-presidente JK, atingido pelo cutelo da repressão antes que Ademar de Barros. Vale referir que, especialmente em relação a JK, não era nem tanto o combate à corrupção que estava em jogo, mas a eliminação de um adversário na disputa pelo poder. A provável candidatura do político mineiro às eleições presidenciais de 1965 (caso fossem realizadas) preocupava uma ala influente dos golpistas de 1964, que não confiavam em JK, mesmo ele tendo apoiado a derrubada de Goulart. As razões para a desconfiança aparecem no editorial do Estadão de 21/04/1964, citado anteriormente. JK era acusado de usar métodos demagógicos e oportunistas 
quando governara o país, o que também implicara aliança com os comunistas e facilidades para sua infiltração nos órgãos públicos. Ademais, acusava o texto, o modo demagógico de JK governar produzira um descalabro financeiro e inflacionário. Depois de afirmar que o governo deveria ir além do expurgo anticomunista e abater também a corrupção, o referido editorial fez uma afirmação peremptória: "a candidatura do sr. Juscelino Kubistchek, por exemplo, está em flagrante e frontal conflito com os propósitos moralizadores da Revolução". O texto termina acusando JK de possuir fortuna incompatível com sua renda e afirmando que seu retorno ao poder significaria a derrota da "revolução". Nessas condições, dizia o editorial, permitir a candidatura de JK seria o cúmulo.

\section{Ilustração suprimida}

\section{por determinação da}

Procuradoria Jurídica

da UDESC a partir de

solicitação formulada

por Cláudio weber

\section{Abramo argumentando}

não cumprimento da

\section{legislação concernente}

\section{a direito autoral.}

Figura 12. O Estado de São Paulo, 28/05/64. Hilde

Evidentemente, estava em ação uma campanha para que o governo suspendesse os direitos políticos de JK eliminando-o, assim, da disputa presidencial. Ressalte-se que a essa altura, maio e junho de 1964, ainda era a forte a crença na realização das eleições presidenciais previstas para 1965. As caricaturas abordaram bastante o cerco a JK, ajudando a reverberar a campanha pela cassação daquele político por meio de recursos cômicos e metafóricos. Na Figura 12, JK é retratado em cenário romano, com desenho que faz apropriação cômica do imaginário sobre a corrupção na fase de decadência da 
velha república. O desenho mostra o então senador brasileiro como se fora membro do antigo senado romano, deitado confortavelmente e comendo saborosas frutas, que na verdade aludem a uma fortuna (6 milhões) certamente de origens duvidosas.

Um dos recursos metafóricos mais comuns nas caricaturas contra JK foi a figura do peixe, uma referência cômica à canção "peixe vivo" que era muita apreciada pelo expresidente e frequentemente cantada por seus admiradores. O recurso ao peixe permitiu que a chargista Hilde mobilizasse diferentes recursos cômicos. Na charge da Figura 13, vemos uma senhora, dona de casa, na verdade uma comissão de inquérito da ditadura, investigando a "geladeira velha" do governo JK. O peixe estragado e malcheiroso que ela encontra serve para evocar a imaginação de coisas podres que teriam sido produzidas no período presidencial de JK.

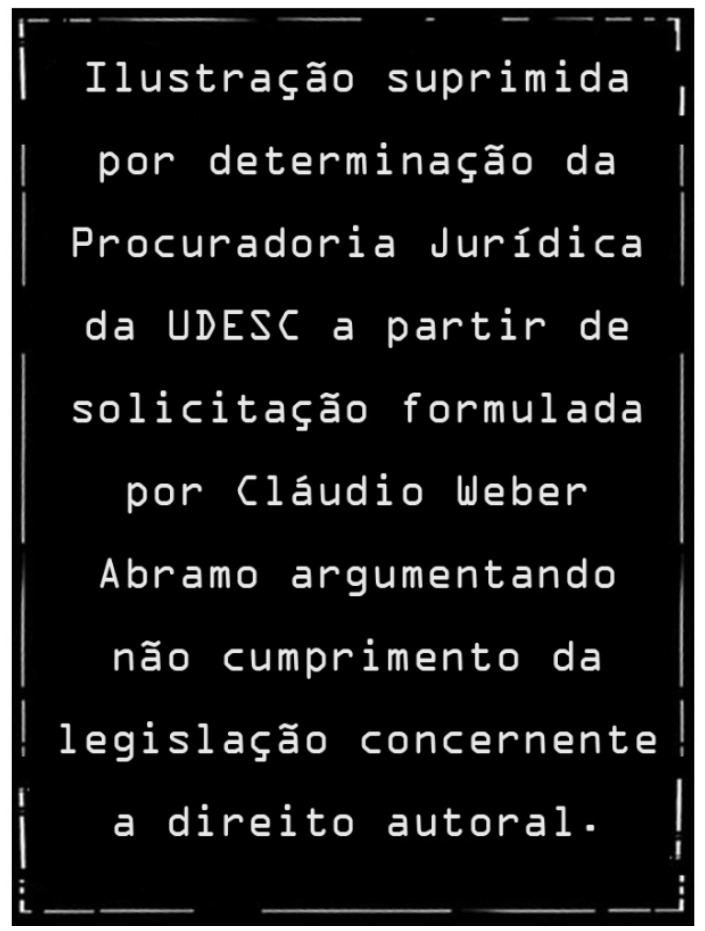

Figura 13. O Estado de São Paulo, 12/05/64. Hilde

Hilde desenhou outras charges adotando o peixe como metáfora de JK. Em uma das mais marcantes (Figura 14), JK é um peixe grande capturado por uma rede, pescado, portanto. Não há texto acompanhando a imagem, de modo que uma identificação cabal é evitada e paira a ambiguidade sobre a identidade do peixe. Entretanto, os traços faciais são claramente de JK, como se pode ver em outros desenhos 
de Hilde. Provavelmente, a falta de menção explícita deveu-se à gravidade da situação, pois a referência sutil remete às tratativas, então em curso nos bastidores, para a cassação do senador. E os traços da imagem não sugerem qualquer desacordo com a possível captura de JK pelas redes da ditadura...

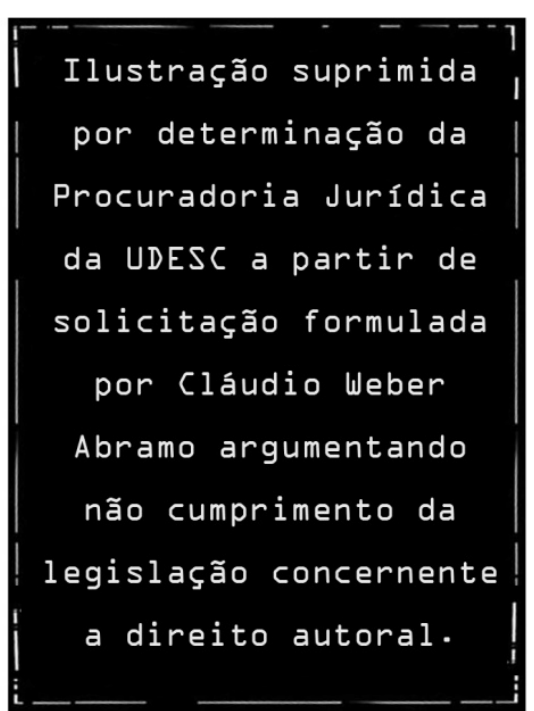

Figura 14. O Estado de São Paulo, 04/06/64. Hilde

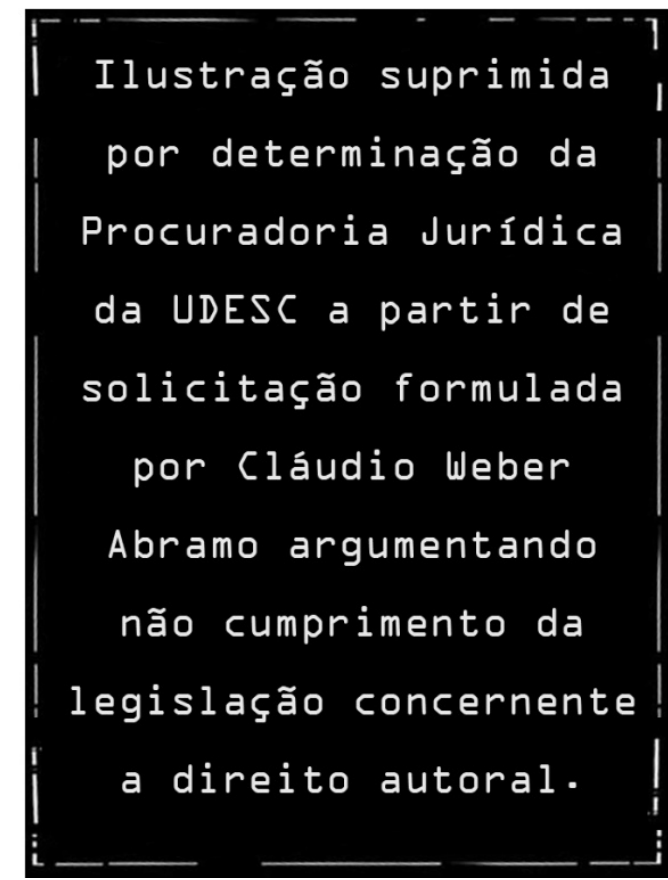

Figura 15. O Estado de São Paulo, 07/06/64, Hilde

Alguns dias depois, a mesma desenhista publicou outra representação cômica sobre a provável saída de JK do palco político, em uma caricatura que mobiliza uma metáfora teatral (Figura 15). Na imagem, o senador é representado como uma bailarina 
Para caracterizar a saída do "cisne" do cenário, Hilde desenhou o palco sendo inclinado para que a "bailarina" deslizasse mais rápido para fora. Pode ser, também, que a caricatura representasse a imagem popular do canto do cisne, ou seja, a última manifestação de um artista ou figura destacada no momento de sua morte. Em 03/06/1964, portanto alguns dias antes da charge, JK havia proferido seu último discurso no Senado, em que tentara deixar um marco discursivo antes de sua cassação, considerada àquela altura bastante provável, tanto que o próprio senador a mencionou. Foi seu canto de cisne.

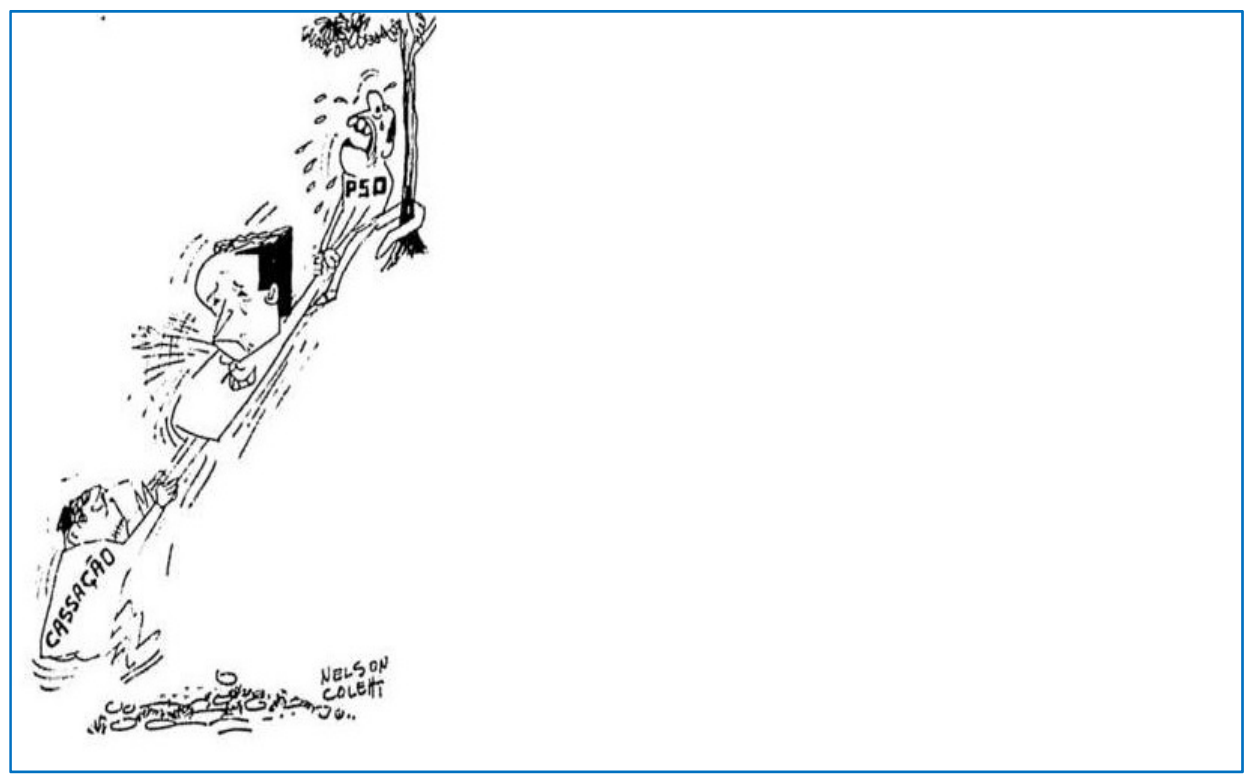

Figura 16. Folha de São Paulo, 30/05/64. Nelson Coletti

A cassação de JK não era apenas desejada, mas demandada por parte da imprensa, no entanto, o assunto era polêmico devido à popularidade do ex-presidente, comprovada em pesquisas de opinião. Além disso, havia líderes do governo contrários à cassação, o que tornava o caso ainda mais delicado ${ }^{12}$. Charges publicadas em outros

\footnotetext{
${ }^{12}$ Uma pesquisa do Instituto Brasileiro de Opinião Pública e Estatística (Ibope), realizada no então estado da Guanabara, em maio de 1964, sobre o tema da cassação mostrou a força da imagem de JK. Enquanto $56 \%$ dos entrevistados disseram ser a favor do expurgo de políticos em geral, apenas $25 \%$ mostraram-se a favor
} 
periódicos também comentaram o episódio, mas em tom diferente ao do Estadão. No exemplo da Figura 16, a charge de Nelson Coletti na Folha de São Paulo mostra a disputa pela cassação de JK, mas com aparente empate entre as forças favoráveis ao expurgo e o PSD (Partido Social Democrático), que se agarra com força a seu candidato para salvá-lo.

No fim das contas, os esforços para evitar a cassação foram derrotados e o ato foi publicado em 08/06/1964, encerrando a carreira política de JK. Em imagem que sugere contentamento pelo desfecho do caso, Hilde voltou ao tema da cassação inspirada nas festas juninas (Figura 17), com uma caricatura em que o menino JK, com olhar decepcionado, vê seu balão "1965" gorar.

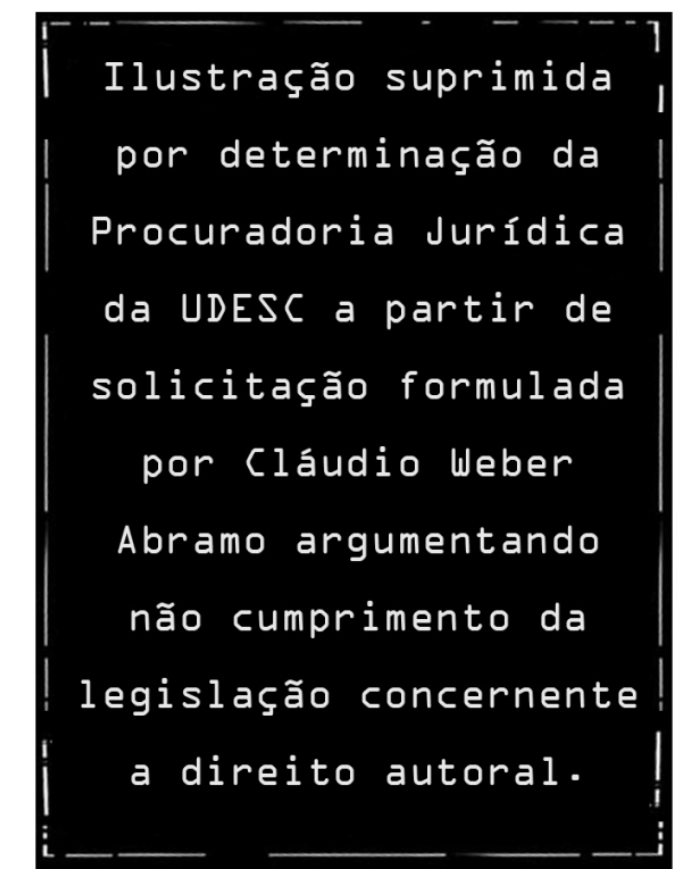

Figura 17. O Estado de São Paulo, 19/06/64. Hilde

No caso de Ademar de Barros, as pressões por sua cassação foram igualmente intensas, mas sem o ingrediente da futura disputa presidencial. Os objetivos dos grupos que o atacavam tinham a ver com disputas regionais em São Paulo, mas também era forte o desejo de atender à ânsia moralizadora, que era sincera em alguns segmentos golpistas. Desde os anos 1940, quando foi interventor em São Paulo durante a ditadura do Estado Novo, Barros era considerado um político corrupto. Ele se envolveu em vários 
escândalos e processos judiciais, o que não impediu sua eleição para a prefeitura e o governo estadual de São Paulo. Os dois diários paulistas analisados nesta pesquisa tiveram rusgas com Barros, especialmente o Estadão, que estava em guerra contra o governador desde os anos 1950. Por isso, o jornal reverberou as críticas mais agudas contra Ademar, também se colocando nesse ponto ao lado dos militares da linha dura, que desejavam sua cabeça em meio ao expurgo anticorrupção.

Entretanto, o destino político de Ademar também interessava à imprensa carioca, como se vê na caricatura da Figura 18, que abordou a principal dificuldade para os interessados na cassação do político paulista: sua participação em favor do golpe. Usando sofisticada metáfora baseada em peça de Shakespeare, Augusto Bandeira retratou Ademar beijando a mão da dama "Revolução" (Pórcia) e verbalizando a fala do mercador de Veneza (Antonio): "Minha doce dama, me haveis devolvido a vida e o meio de viver..."13.

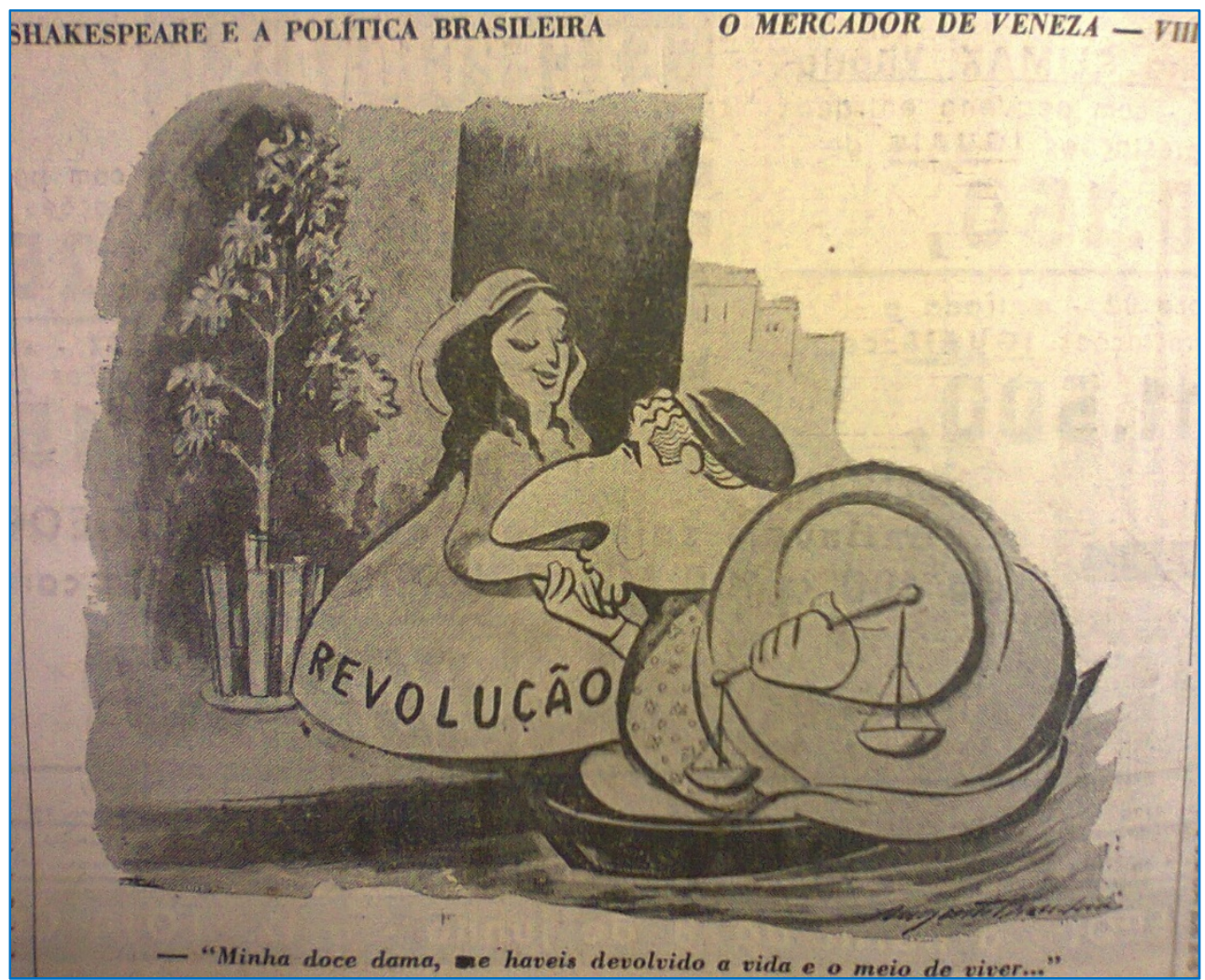

Figura 18. Correio da Manhã, 31/05/1964. Augusto Bandeira

\footnotetext{
${ }^{13} \mathrm{O}$ desenho faz parte de uma genial série de caricaturas de Augusto Bandeira sobre os principais líderes da época, interpretados à luz das tragédias de Shakespeare. A crise de 1964 inspirou o criativo artista a associar a tragédia e a comédia para representar o drama político brasileiro.
} 
A ironia do desenho sugere a relação oportunista do político com o Golpe de 1964, de que foi apoiador de primeira hora e peça-chave. Como governador de São Paulo, Ademar teve papel importante na mobilização direitista prévia aos eventos, e também para seu sucesso militar. Como assumira posição entre os principais líderes civis do movimento, ficava difícil cassá-lo, pois ele usava a "revolução" como blindagem. Aliás, esse tema foi muito mobilizado pelos chargistas, que mostraram Ademar usando a ditadura como armadura ou como camuflagem contra as investigações e os inquéritos (figuras 19 e 20). No caso da Figura 19, note-se o "31 de março" escrito na armadura e a “caixinha” pendurada atrás da armadura, um adereço metafórico frequente para associar Ademar de Barros à corrupção. No caso da Figura 20, no capacete militar que camufla o político há uma bandeirinha onde se lê "31 de 3", também uma alusão à data do golpe.

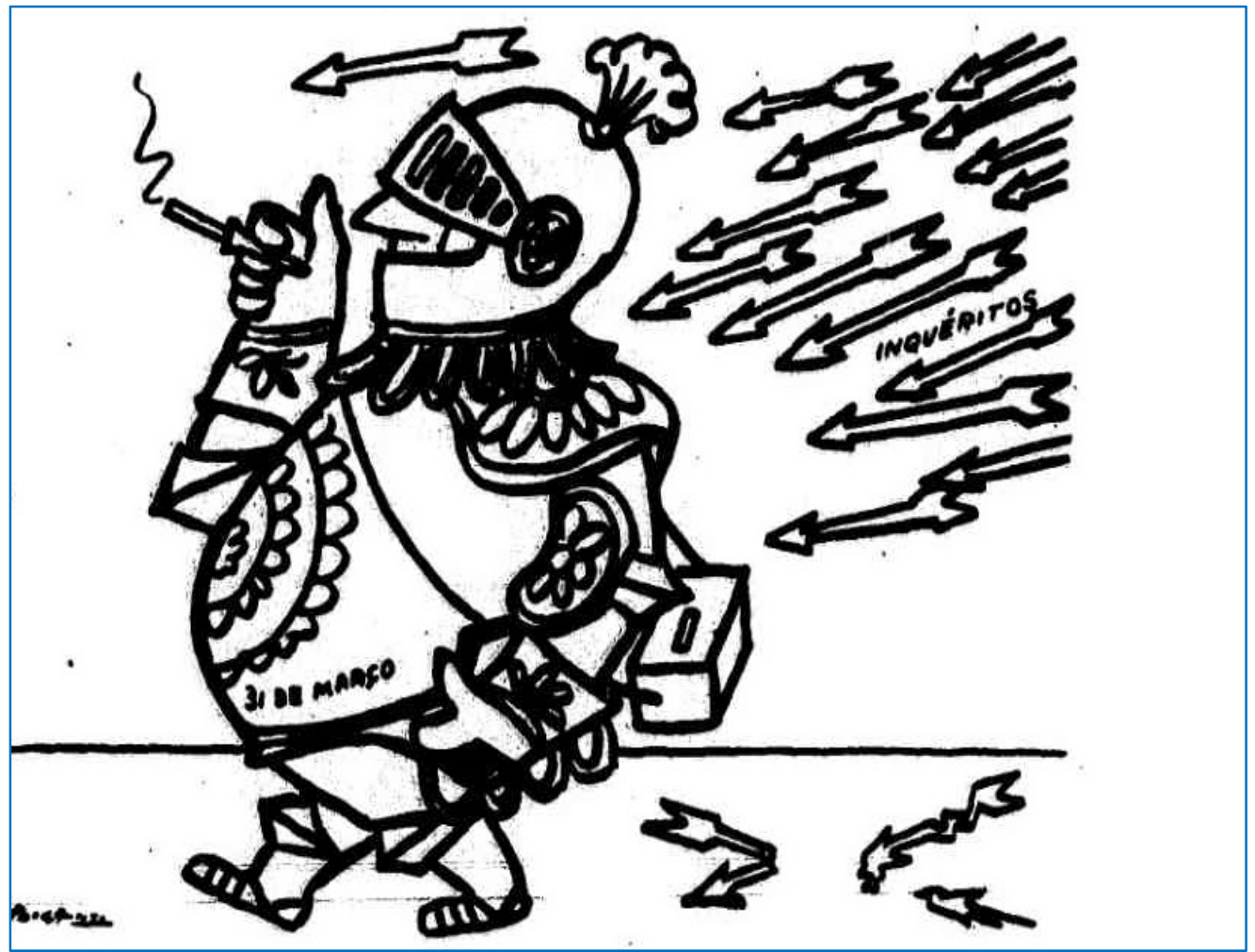

Figura 19. O Estado de São Paulo, 20/08/64. Biganti 


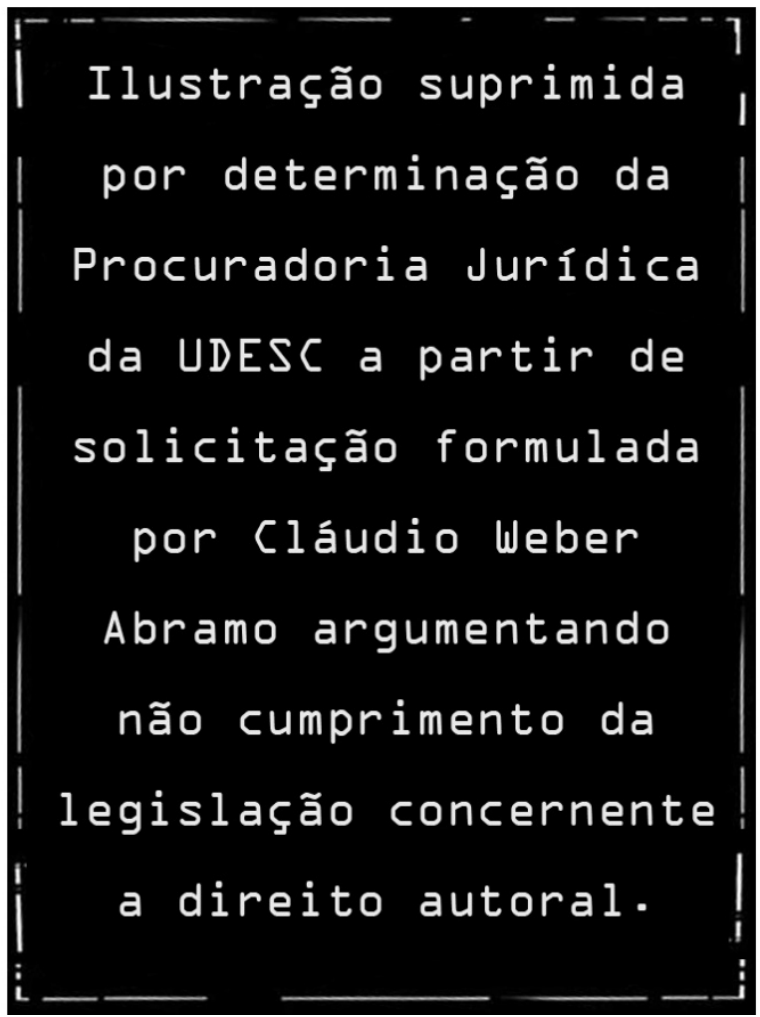

Figura 20. O Estado de São Paulo, 06/06/64. Hilde

No mesmo período em que ocorreram pressões para a cassação de JK, a mira dos chargistas também se voltou contra Ademar. Ele foi retratado em várias situações relacionadas às investigações contra a corrupção e sempre buscando meios para se esconder e fugir, ou contando as horas para terminar o prazo de vigência do Ato Institucional, como na Figura 21. No final do prazo, ele realmente escapou da cassação, o que inspirou a caricatura "O Intocável”, publicada por Hilde no Estadão (Figura 22), em que Ademar aparece como um pistoleiro hábil e bem armado, difícil de ser abatido. A propósito das armas, nos bastidores políticos comentava-se que um dos trunfos do governador de São Paulo era a força armada estadual, composta por 30 mil homens, que Barros ameaçava mobilizar caso o governo federal agisse contra ele ${ }^{14}$.

\footnotetext{
${ }^{14}$ Informação retirada de relatórios do consulado norte-americano em São Paulo. National Archives and Records Administration (NARAII). RG: 286 - 250 - 66 /3/01, caixa 20, pasta 3. Sobre o processo de cassação de Ademar de Barros cf. HAYASHI, Marli Guimarães. A gênese do ademarismo (1938-1941). Dissertação de Mestrado defendida na Universidade de São Paulo, 1996.
} 


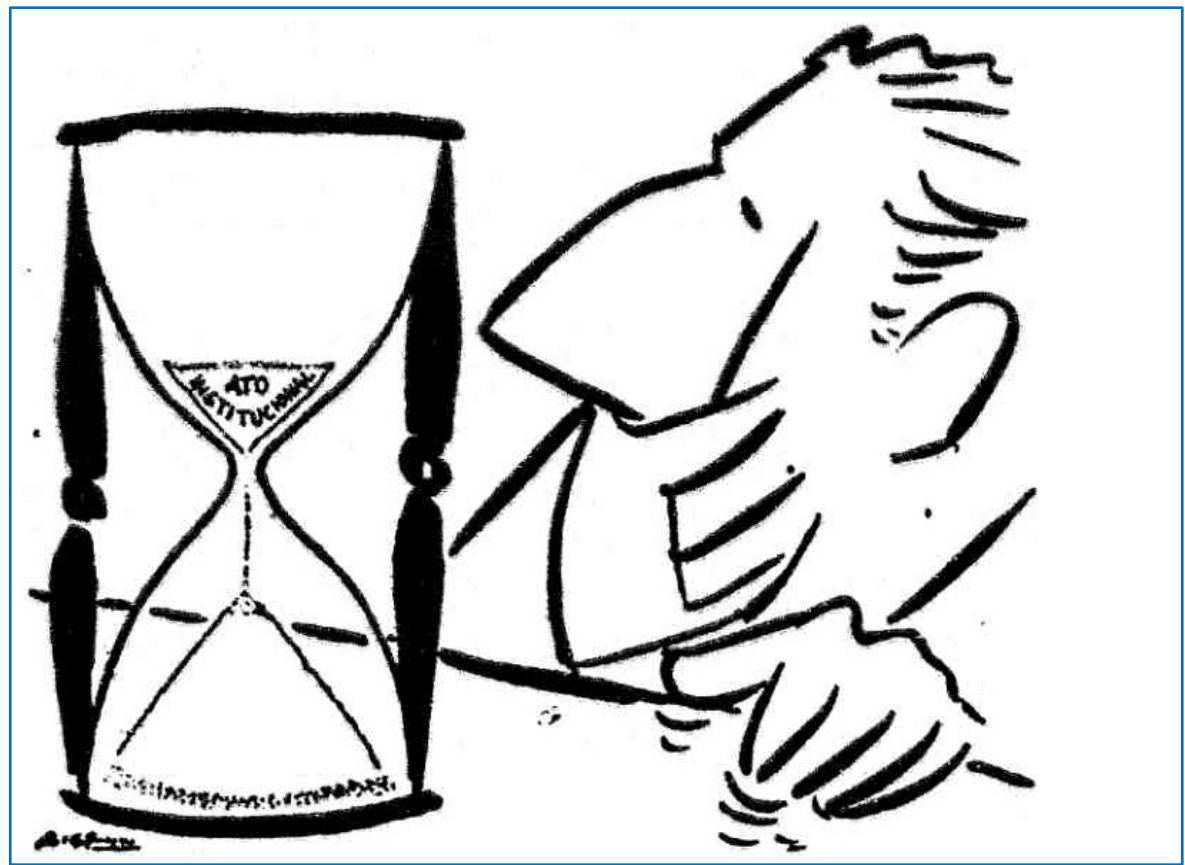

Figura 21. O Estado de São Paulo, 09/06/64. Biganti

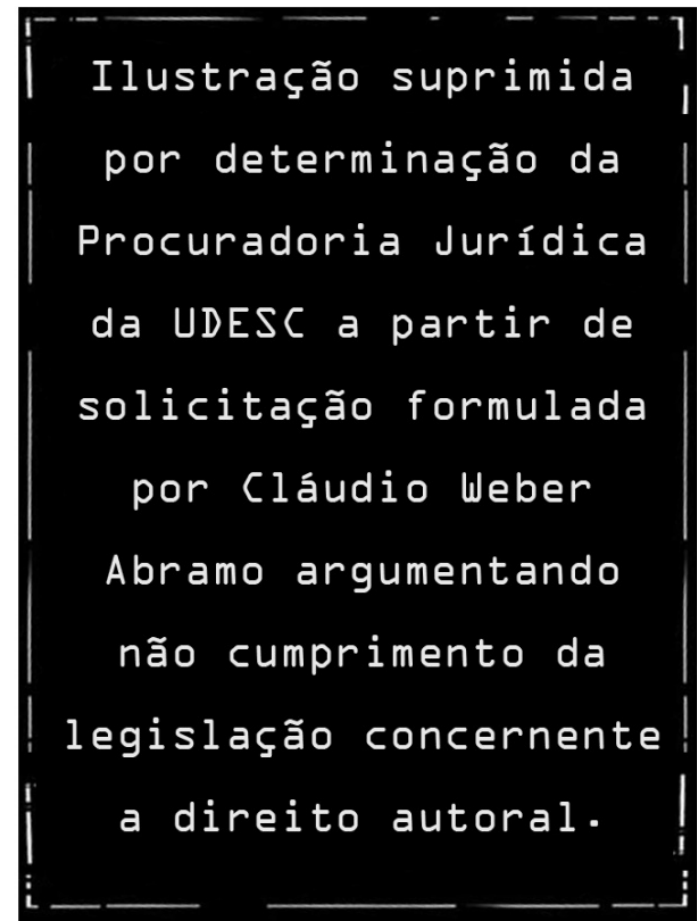

Figura 22. O Estado de São Paulo, 13/08/64. Hilde

Entretanto, as "armas" de Ademar não foram suficientes para salvá-lo de uma segunda crise, que terminou com sua remoção do governo de São Paulo e cassação de direitos políticos, em junho de 1966. A imprensa paulista, que manteve pressão sobre o 
governador durante todo o período, naturalmente comemorou sua saída do poder, em charges que mostravam alívio apesar da demora ("antes tarde do que nunca" foi o título de uma dessas charges). Contudo, a real razão para a cassação de Ademar não foi o problema da corrupção, pois, apesar das pressões da imprensa e da linha dura, o governo de Castelo Branco havia impedido que os inquéritos atingissem o governador paulista ${ }^{15}$. A cassação decorreu da aproximação de Ademar de Barros com a oposição e de articulações para vencer as eleições indiretas em São Paulo (no final de 1966), contrariando a vontade de Brasília.

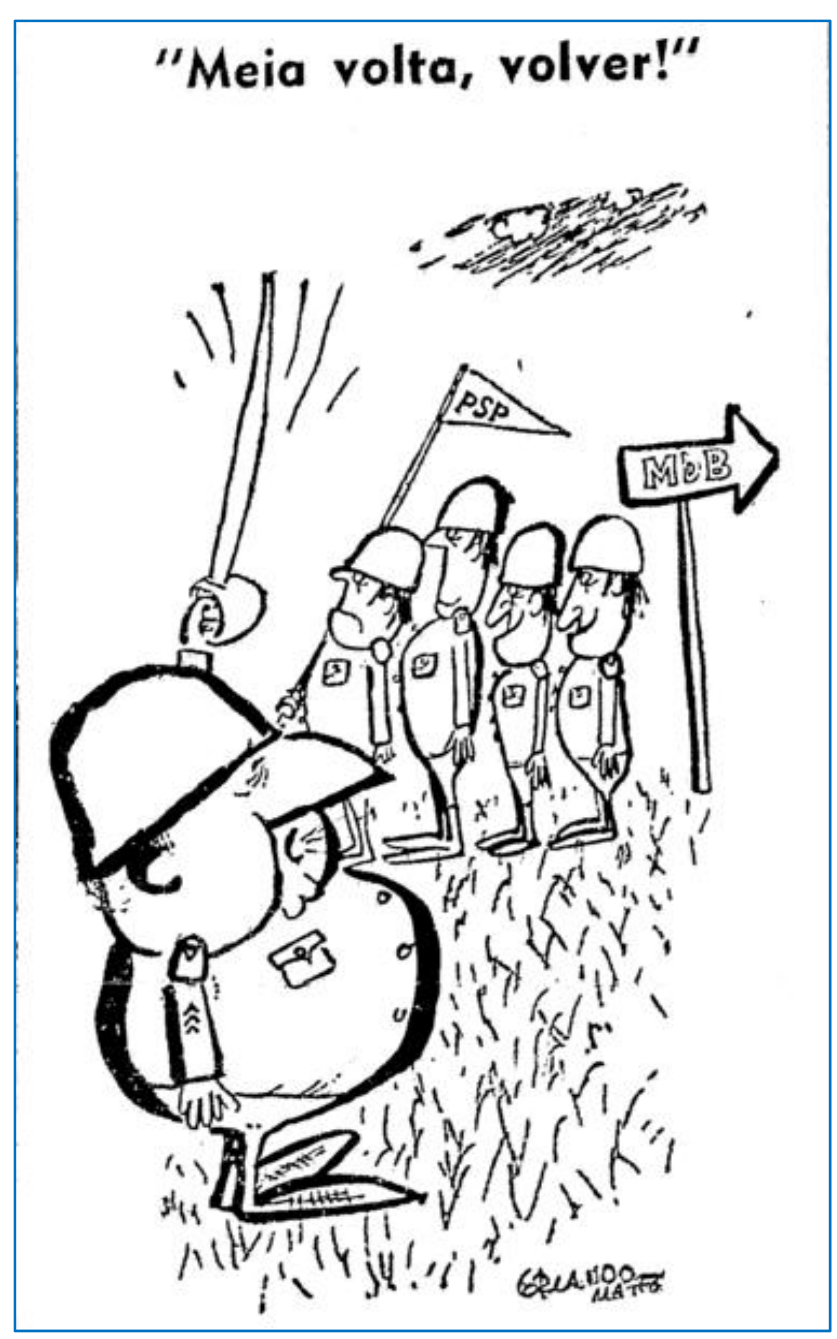

Figura 23. Folha de São Paulo, 03/06/66. Orlando Mattos

\footnotetext{
${ }^{15}$ Segundo fontes ligadas ao consulado norte-americano, Castelo Branco chegou a remover um oficial militar da chefia de uma comissão de inquérito que visava a encontrar provas de atos corruptos de Ademar. (NARAII). RG 59, caixa 29, pasta 6.
} 
Duas charges publicadas dias antes da intervenção federal em São Paulo mencionaram os movimentos políticos de Ademar que selaram seu destino. A charge da Figura 23 comenta, com ironia, a passagem das tropas de Ademar para o lado do partido de oposição à ditadura, o MDB (Movimento Democrático Brasileiro). Orlando Mattos, caricaturista da Folha, desenhou Ademar levando seus quadros do extinto Partido Social Progressista (PSP) para o partido que deveria ocupar o espaço da oposição no sistema bipartidário criado pela ditadura. Já na imagem da Figura 24, o governador aparece fazendo nomeações em profusão para cargos públicos em São Paulo, como tentativa de influenciar o resultado das futuras eleições. Foram seus últimos atos à frente do governo paulista.

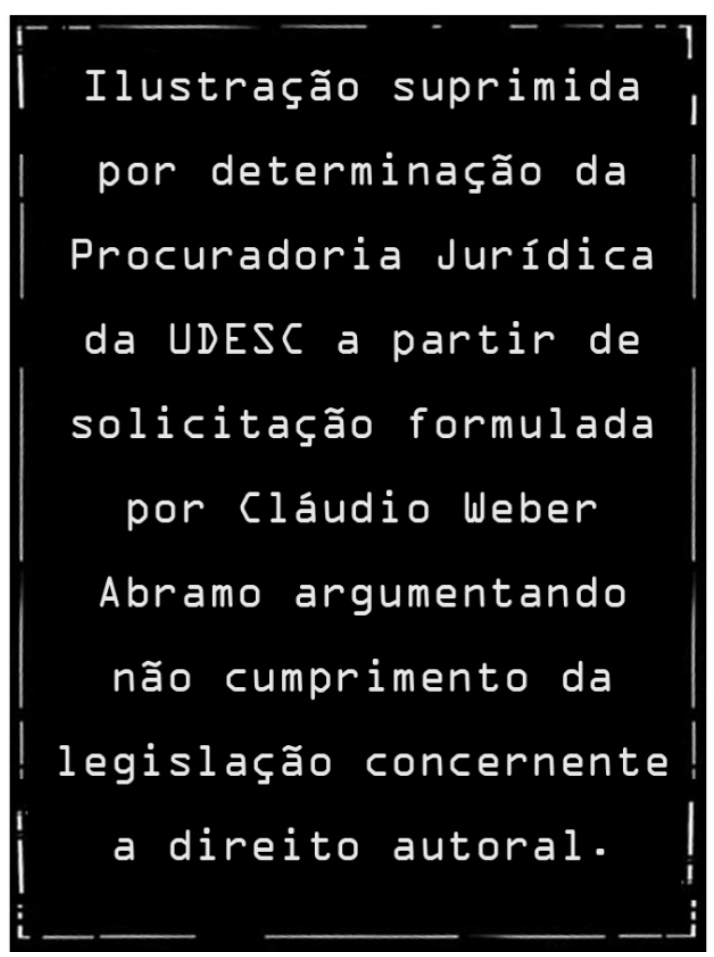

Figura 24. O Estado de São Paulo, 04/06/66. Hilde

\section{Considerações finais}

Em sua atuação, os jornais contribuíram para justificar o regime autoritário e atrair apoio público para a ditadura, com as exceções que foram apontadas. Entretanto, não se tratou de apoio passivo, já que agiram segundo uma pauta própria e fizeram pressão para que o Estado atendesse às suas demandas e preferências. 
Como se procurou mostrar, as caricaturas da grande imprensa tiveram papelchave na construção de representações sobre os expurgos promovidos pela ditadura, ajudando a instituir o tema dos dois principais inimigos da "revolução", que constituíam sua razão de ser. Essa contribuição foi especialmente importante no caso da corrupção, que as caricaturas figuraram em traços cômicos e metáforas populares, em contraste com a nada engraçada violência dos expurgos.

No texto, foram enfatizados dois casos exemplares da campanha contra a corrupção, embora outras figuras proeminentes tenham sido envolvidas em episódios ocorridos nos anos seguintes. O tema da luta contra a corrupção permaneceu importante nos discursos e nas práticas da ditadura e mobilizou a convicção e a esperança de muitos de seus apoiadores. Com o recrudescimento autoritário no contexto do $\mathrm{Al5}$, a campanha anticorrupção ganhou novo fôlego, mas efêmero. Os projetos de crescimento econômico da ditadura geraram grandes obras e negócios, mas também oportunidades para negociatas. Figuras de destaque dos governos militares envolveram-se em casos escusos, todos devidamente abafados pelos órgãos oficiais, tanto mais porque a imprensa vivia sob o peso da censura.

Para uma correta compreensão do tema, portanto, há que se estar atento para outros usos da campanha anticorrupção, especialmente a busca de popularidade para o governo e a remoção de desafetos do cenário político. As ações da ditadura contra a corrupção nunca foram às últimas consequências, tampouco atingiram lideranças importantes do campo governista. Na prática, as pessoas punidas efetivamente por corrupção eram peixes pequenos do cenário político (como Moisés Lupion) ou, então, modestos funcionários públicos. Figuras de destaque do campo favorável à ditadura foram poupadas das investigações (por exemplo, Delfim, Maluf, Andreazza), enquanto certas personalidades foram expurgadas por motivações que nada tinham a ver com luta anticorrupção, como JK e Ademar de Barros. Com a análise desses episódios, procurou-se revelar o potencial de utilização oportunista da luta contra a corrupção, cuja manipulação prestou-se a justificar o expurgo de líderes incômodos para os governos da ditadura.

A corrupção seguiria um tema importante no debate político brasileiro, como bem sabemos hoje. As campanhas anticorrupção ofereceriam novas oportunidades de 
mobilização caricatural e de apropriação oportunista, com fins diversos do que o propalado objetivo de aperfeiçoar as instituições da república.

\section{Referências}

DELPORTE, Christian. Les ambivalences du pouvoir e des politiques. In:DELGADO, MarieMelódie (Org.). La caricature ... et si c'était sérieux? décryptage de la violence satirique. Paris: Nouveau Monde Éditions, 2015, p.48-57.

HAYASHI, Marli Guimarães. A gênese do ademarismo (1938-1941). 1996. Dissertação (Mestrado em História) -Universidade de São Paulo, São Paulo, 1996.

MOTTA, Rodrigo P.S. Jango e o golpe de 1964 na caricatura. Rio de Janeiro: Zahar, 2006.

MOTTA, Rodrigo P.S. A ditadura nas representações verbais e visuais da grande imprensa: 1964-1969. Topoi, v. 14, n. 26, p. 62-85, jan./jul. 2013.

ROMERO, Marcelo. O governo Fernando Henrique Cardoso na charge de Angeli: os tons e contornos da crítica política no traço do artista. 2015. Tese (Doutorado em História), UFJF, Juiz de Fora, 2015.

Recebido em 07/07/2016 Aprovado em 26/08/2016

Universidade do Estado de Santa Catarina - UDESC Programa de Pós-Graduação em História - PPGH

Revista Tempo e Argumento Volume 08 - Número 18 - Ano 2016 tempoeargumento@gmail.com 